\title{
VEGETATIVE PROPAGATION OF HYMENAEA COURBARIL L. AND APULEIA LEIOCARPA (VOGEL) J. F. MACBR. BY MINI-CUTTING
}

\author{
Juliana Muller Freire $2^{*} \odot$, Letícia Nakamura Veríssimo ${ }^{3} \odot$, Beatriz Rodrigues Pereira $^{4} \odot$, Janaína Ribeiro
} Costa Rouws ${ }^{5}$ a and José Carlos Arthur Junior ${ }^{6}$ (ㄷ)

\footnotetext{
${ }^{1}$ Received on 06.08.2019 accepted for publication on 17.12.2019.

${ }^{2}$ Empresa Brasileira de Pesquisa Agropecuária, Seropédica, RJ - Brasil. E-mail: <juliana.muller@embrapa.br>.

${ }^{3}$ Universidade Federal Rural do Rio de Janeiro,Graduando em Engenharia Florestal, Seropedica, RJ - Brasil. E-mail: <leticia.verissimo@ hotmail.com>.

${ }^{4}$ Faculdade de Economia da Universidade do Porto,Programa de Pós-Graduação em Gestão de Ambiente,Porto - Portugal. E-mail: $<$ beatrizrpereira@yahoo.com.br>.

${ }^{5}$ Empresa Brasileira de Pesquisa Agropecuária, Seropédica, RJ - Brasil. E-mail: <janaina.rouws@embrapa.br>.

${ }^{6}$ Universidade Federal Rural do Rio de Janeiro,Instituto de Florestas, Seropédica, RJ - Brasil. E-mail: <josecarlosarthurjunior@gmail.com>. *Corresponding author.
}

\begin{abstract}
The objective of this work was to evaluate the vegetative propagation of Hymenaea courbaril (jatobá) and Apuleia leiocarpa (garapa) using the mini-cutting technique with the use of indolebutyric acid (IBA) growth regulator in different types of mini-cuttings. Two experiments were set up: the first involving the two species and three mini-cutting techniques (basal, intermediate and apical) in the presence and absence of IBA (4000 mg kg-1). In the second experiment, only the garapa species was evaluated by testing the same three mini-cutting techniques at four IBA concentrations: 0, 1000, 2000 and $4000 \mathrm{mg} \mathrm{kg}^{-1}$. The mini-cuttings were obtained from 6-month-old seedlings produced from seeds in a nursery. A randomized block design was used in a $3 \times 2 \times 3$ factorial scheme (three mini-cutting techniques, two IBA concentration levels and three evaluation dates) in the first experiment, and a $3 \times 4 \times 3$ factorial scheme (three mini-cutting techniques, four IBA concentrations and three evaluation dates) in the second experiment. At 90 days, jatobá had an average survival of $54 \%$, with less than $5 \%$ of total rooting, without significant influence of the mini-cutting technique or IBA use. Garapa presented higher survival for the basal mini-cuttings in both experiments, which were the only ones that took root. IBA did not influence survival or rooting percentage of garapa mini-cuttings, but negatively influenced the root number, length and dry mass. We concluded that the basal mini-cutting is a viable technique for vegetative propagation of garapa, presenting $40 \%$ of rooting, but the propagation by minicutting for jatobá was not successful under the conditions of this study.
\end{abstract}

Keywords: Rooting; auxin; Fabaceae.

\section{PROPAGAÇÃO VEGETATIVA DE HYMENAEA COURBARIL L. E APULEIA LEIOCARPA (VOGEL) J. F. MACBR. POR MEIO DA MINIESTAQUIA}

RESUMO - O trabalho teve como objetivo avaliar a propagação vegetativa de Hymenaea courbaril (jatobá) e Apuleia leiocarpa (garapa) por meio da técnica de miniestaquia com o uso do regulador de crescimento, ácido indolbutírico (AIB), em diferentes tipos de miniestacas. Foram montados dois experimentos, o primeiro envolvendo as duas espécies, três tipos de miniestacas (basais, intermediárias e apicais), na presença e ausência de AIB (4000 mg kg-1). No segundo experimento, avaliou-se apenas a espécie garapa testando-se os mesmos três tipos de miniestacas em quatro concentrações de AIB: 0, 1000, 2000 e $4000 \mathrm{mg} \mathrm{kg}^{-1}$. As miniestacas foram obtidas a partir de mudas de 6 meses de idade, produzidas em viveiro a partir de sementes. Utilizou-se delineamento em blocos casualizados no esquema fatorial $3 \times 2 \times 3$ (três tipos de miniestacas, dois níveis de AIB e três datas de avaliação) no primeiro experimento, e 3 × 4 × 3 (três tipos de miniestacas, quatro concentrações de AIB e três datas de avaliação) no segundo experimento. Aos 90 dias, o jatobá apresentou sobrevivência média de $54 \%$, com menos de $5 \%$ de enraizamento total, sem influência significativa do tipo de miniestaca ou do uso do AIB. Em ambos os experimentos a garapa apresentou maior sobrevivência para as miniestacas basais, que foram as únicas que enraizaram. O AIB não influenciou a sobrevivência e o percentual de enraizamento de miniestacas da garapa, porém influenciou de forma negativa o número, comprimento e massa seca de raiz. Conclui-se

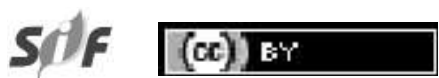

Revista Árvore 2020;44:e4405 http://dx.doi.org/10.1590/1806-908820200000005 
para garapa que a miniestaquia, a partir das miniestacas basais se mostrou uma técnica viável, com $40 \%$ de enraizamento, porém para jatobá, nas condições do estudo, a propagação por miniestaquia não teve sucesso.

Palavras-Chave: Enraizamento; Auxina; Fabaceae.

\section{INTRODUCTION}

Hymenaea courbaril L., popularly known as jatobá, has a wide geographical distribution, naturally occurring in the Amazon, Caatinga, Cerrado, Atlantic Forest, and Pantanal biomes in several states and regions of Brazil (Lima and Pinto, 2015). Jatobá belongs to the Fabaceae family, and has food, timber, landscape and medicinal potential. Its wood is highly valued for having high density, hardness and mechanical resistance, and therefore it is highly recommended for use in the furniture and construction industries (Lorenzi, 1992).

Apuleia leiocarpa (Vogel) J. F. Macbr., popularly known as garapa, grápia, or amarelão, belongs to the Fabaceae family, and has natural distribution in the Amazon, Caatinga, Cerrado, and Atlantic Forest biomes (Lima, 2015). It is a deciduous tree that reaches up to 35 $\mathrm{m}$ and $100 \mathrm{~cm}$ in diameter at breast height (Carvalho, 2003). Its wood has a high economic value with several uses. Due to the intense logging and fragmentation of its habitat, it is suspected that the population has suffered a reduction of at least $30 \%$ in the last 100 years and is considered endangered (CNC Flora, 2012). In addition, the species has irregular fruiting and a large size, making it difficult to collect its fruit (Carvalho, 2003).

Vegetative propagation techniques, including cutting and mini-cutting, are an alternative to overcome the difficulties in propagating native species and can be used for commercial purposes, as well as assisting in the rescue and conservation of genetic forest resources (Dias et al., 2012). Cutting is a method of asexual propagation, which consists in removing and using parts of the mother plant to be multiplied. Mini-cutting is a newer technique with the principle being to harness the juvenile potential of the propagules for rooting induction (Ferriani et al., 2010). As this technique involves juvenile rather than woody material, mini-cuttings may provide greater rhizogenic potential, larger number of propagules and reduced seedling formation time in the nursery (Menezes et al., 2018).

The rooting of cuttings and mini-cuttings varies among species and between clones/progenies of the same species (Neubert et al., 2017), and may be influenced by intrinsic plant-related factors and extrinsic factors related to environmental conditions. Intrinsic factors include the genetic constitution of the plant, the endogenous level of inhibitors, cutting techniques, plant age and nutritional and water conditions of the parent plant (Cavalcante et al., 2019; Guimarães et al., 2019). Among the relevant extrinsic factors are the time of year of collection, use of growth regulators, substrate quality, and the environmental conditions (temperature, light and humidity) (Hartmann et al., 2011; Peralta et al., 2017; Freitas et al., 2017b; Marchi et al., 2018).

For species with difficulty in rooting, an alternative is the use of plant growth regulators which can promote, inhibit or modify plant morphological and physiological processes at low concentrations (Lacerda et al., 2007). Among these regulators are auxins, among which in turn are indole-3-acetic acid (IAA), indolebutyric acid (IBA) and $\alpha$-naphthalenoacetic acid (NAA).

Several native species have already shown positive responses to auxin application, such as Paubrasilia echinata Lam (Endres et al., 2007), Trichilia catigua A. Juss. (Valmorbida et al., 2008), Cariniana estrellensis (Raddi) Kuntze, Piptadenia gonoacantha (Mart.) J.F.Macbr. (Hernández et al., 2012), Schizolobium parahyba var. amazonicum (Huber ex Ducke) Barneby (Lima et al., 2018), and Ilex paraguariensis St. Hil (Bisognin et al., 2017).

However, IBA may present quite a variable response according to species, cutting technique, concentration, or application mode, among others (Lima et al., 2018; Emer et al., 2016; Yamamoto et al., 2010).

In view of the above, the objective of this work was to evaluate the potential of vegetatively propagating Apuleia leiocarpa (garapa) and Hymenaea courbaril (jatobá) by testing different concentrations of IBA growth regulator and mini-cutting techniques.

\section{MATERIAL AND METHODS}

Two experiments were carried out in the "Luiz Fernando de Oliveira Capellão" forest nursery of the Department of Forestry, Forest Institute of the Federal Rural University of Rio de Janeiro, located 
in Seropédica/RJ (latitude $22^{\circ} 45^{\prime} \mathrm{S}$ and longitude $\left.43^{\circ} 41^{\prime} \mathrm{W}\right)$. The climate of the region is Aw according to the Köppen classification (Ramos et al., 1973), and the maximum average annual temperature is $29.0^{\circ} \mathrm{C}$ and the minimum average is $19.8^{\circ} \mathrm{C}$ in the last 10 years, according to the average data from the Agricultural Ecology Meteorological Station Km 47 - Seropédica/ PESAGRO - RIO. In addition, the average rainfall is $1,152 \mathrm{~mm}$ per year, concentrated between December and March, with the lowest rainfall in July and August.

Indolebutyric acid (IBA) powder was used at a concentration of $4,000 \mathrm{mg} \mathrm{kg}^{-1}$ in the first experiment carried out from March to June 2017 using Apuleia leiocarpa (garapa) and Hymenaea courbaril (jatobá) species. The influence of the presence or absence of the hormone without varying the concentration, three minicutting techniques (basal, intermediate and apical) were evaluated at 30,60 and 90 days after planting (DAP). The experimental design was a randomized block design in a $3 \times 2 \times 3$ factorial scheme with three mini-cutting techniques, two levels of growth regulator (with or without IBA) and the three evaluation dates. In the first rooting evaluation, $50 \%$ of the cuttings of each repetition were sampled and then the others in the second. Plots of ten mini-cuttings were repeated five times.

The second experiment was conducted from February to May 2018 only with the garapa, in which different IBA powder concentrations $(0,1000,2000$ and $4000 \mathrm{mg} \mathrm{kg}^{-1}$ ) were evaluated in three mini-cutting techniques (basal, intermediate and apical) and evaluated on three dates at 30, 60 and 90 days after planting (DAP). The experimental design was a randomized block design in a $3 \times 4 \times 3$ factorial scheme with the three mini-cutting techniques, the four IBA concentrations and the three evaluation dates. There were five repetitions of eight mini-cuttings per plot for each treatment.

Garapa seeds were collected from a forest fragment located in Paracambi/RJ, while jatobá seeds were collected from parent plants located at the UFRRJ campus in Seropédica/RJ. The seedlings of both species were produced in the nursery of UFRRJ, using polyethylene bags with 2.0 liters of volumetric capacity as plastic containers. The substrate was composed of a mixture of subsoil soil, cattle manure and sand in a ratio of 5:4:1. This substrate received basic fertilization as recommended by Gonçalves et al. (2000), with the following doses per $\mathrm{m}^{3}$ of substrate: $150 \mathrm{~g}$ of $\mathrm{N}$, using ammonium sulfate; $300 \mathrm{~g}$ of $\mathrm{P}_{2} \mathrm{O}_{5}$, through the use of simple superphosphate; $100 \mathrm{~g}$ of $\mathrm{K}_{2} \mathrm{O}$ by the use of potassium chloride; and $150 \mathrm{~g}$ of FTE Br $12(1.8 \% \mathrm{~B}, 0.8 \%$ $\mathrm{Cu}, 3.0 \% \mathrm{Fe}, 2.0 \% \mathrm{Mn}$ and $0.1 \% \mathrm{Mo}$ ) for micronutrient supply. Coverage fertilization was performed according to the recommendation of Gonçalves et al. (2000), being composed of $200 \mathrm{~g}$ of $\mathrm{N}$ by ammonium sulfate and 180 $\mathrm{g}$ of $\mathrm{K}_{2} \mathrm{O}$ by potassium chloride to 100 liters of nutrient solution, applying $5 \mathrm{ml}$ per seedling. The first cover fertilization occurred after 30 days of sowing, repeating every 15 days for nitrogen fertilization, and every 30 days for potassium fertilization. During the seedling production, the containers remained in beds under full sun on the ground covered with gravel, and daily irrigations were performed two to three times in a daily volume of $15 \mathrm{~mm}$ by sprinkler system.

Jatobá and garapa mini-cuttings were obtained from seedlings approximately six months old, and 100 $\mathrm{cm}$ and $45 \mathrm{~cm}$ high, respectively. Basal, intermediate and apical mini-cuttings of each seedling were performed in both species, approximately $12 \mathrm{~cm}$ long, with the leaf area being reduced to $25 \%$ of the initial size. The minicuttings were collected using pruning shears, placed in containers with water to prevent dehydration and taken to a covered area of the nursery, until its staking in the substrate. No pest disinfestation treatment was performed.

For preparing the IBA in talc, 0.1 to $0.4 \mathrm{~g}$ of IBA (depending on the treatment) was mixed in industrial talc until completing $100 \mathrm{~g}$. Sufficient alcohol was added to form a paste for better homogenization, then transferred to a greenhouse at $40{ }^{\circ} \mathrm{C}$, where the mixture remained until complete evaporation of the solvent (Yamamoto et al., 2010). Growth regulator application was performed by introducing the moistened mini-cut base into the powder container approximately $1 \mathrm{~cm}$ from the base, and then the mini-cut was planted on the substrate at a depth of 2 to $3 \mathrm{~cm}$.

The culture vessels in experiment 1 were $280 \mathrm{~cm}^{3}$ volume polypropylene tubes with eight longitudinal striations, while $50 \mathrm{~cm}^{3}$ volume polypropylene tubes with six longitudinal striations were used in experiment 2. The containers were supported on polypropylene box trays. The substrate used in both experiments was composed of peat and vermiculite.

After planting the mini-cuttings in the substrate, they were kept in a greenhouse on benches suspended for 90 days with a temperature between 25 to $30^{\circ} \mathrm{C}$ and relative humidity above $60 \%$. Irrigation was performed daily by

Revista Árvore 2020;44:e4405 
nebulization. The temperature control in the greenhouse was done through a temperature sensor which triggered the misting system when the air temperature reached $30{ }^{\circ} \mathrm{C}$ and turned off when the temperature dropped to $25^{\circ} \mathrm{C}$. At night the system was shut down and resumed from 06 to 18 hours.

Three survival evaluations were performed at 30,60 and 90 days after planting, and two rooting evaluations at 60 and 90 days. In the first rooting evaluation, $50 \%$ of the mini-cuttings of each repetition were sampled, and then the others in the second. We observed the formation of roots and calluses, as well as the absence of roots and calluses in these evaluations.

When the presence of a root was observed in the second experiment, they were counted, measured with a graduated ruler and placed in an oven at $70{ }^{\circ} \mathrm{C}$ for two days to determine the dry mass in a digital analytical scale.

The results were submitted to tests to verify compliance with the assumptions for the analysis of variance. The variance analyzes were performed once the assumptions were met, the Scott-Knott clustering method was applied at $5 \%$ probability if there were differences by the F-test between factor levels for the mini-cutting technique, and regression adjustments were performed for the different IBA concentrations or evaluation dates. Statistical analysis was performed using the R program (R Core Team, 2018).

\section{RESULTS}

\subsection{Experiment 1}

Only the isolated evaluation date factor was significant from the results of the analysis of variance for jatobá. The average survival of jatobá cuttings was 90\% at 30 days, and reduced up to 90 days (Table 1). Regardless of the evaluation date, there was no significance between survival averages in comparing cutting techniques and between the general averages obtained with or without the use of IBA.

The average survival for garapa was $85 \%$ at 30 days, decreasing to $12 \%$ at 90 days (Table 1 ). The basal mini-cuttings had better survival than the other mini-cuttings $(\mathrm{P}<0.05)$ in all evaluations, regardless of the addition of the IBA (Table 1). The intermediate and apical mini-cuttings had total mortality at 90 days. Regardless of the cutting technique, the application of IBA reduced the survival percentage of mini-cuttings at 30 days. Only $5 \%(n=15)$ of the 300 jatobá minicuttings took root in the experiment, $3 \%$ of apical minicuttings, $1.6 \%$ intermediate and $0.3 \%$ basal. There were $17.3 \%(\mathrm{n}=52)$ with callus formation, with $9.6 \%(\mathrm{n}=29)$

Table 1 - Average survival of apical, intermediate and basal mini-cuttings of Hymenaea courbaril (jatobá) and Apuleia leiocarpa (garapa) at 30, 60 and 90 days after planting (DAP) with (+) and without (-) indolebutyric acid (IBA) at the concentration of $4000 \mathrm{mg} \mathrm{kg}^{-1}$.

Tabela 1 - Sobrevivência média de miniestacas apicais, intermediárias e basais de Hymenaea courbaril (jatobá) e Apuleia leiocarpa (garapa) aos 30, 60 e 90 dias após o plantio (DAP) com (+) e sem (-) aplicação de ácido indolbutírico (AIB) na concentração $4.000 \mathrm{mg} \mathrm{kg}^{-1}$

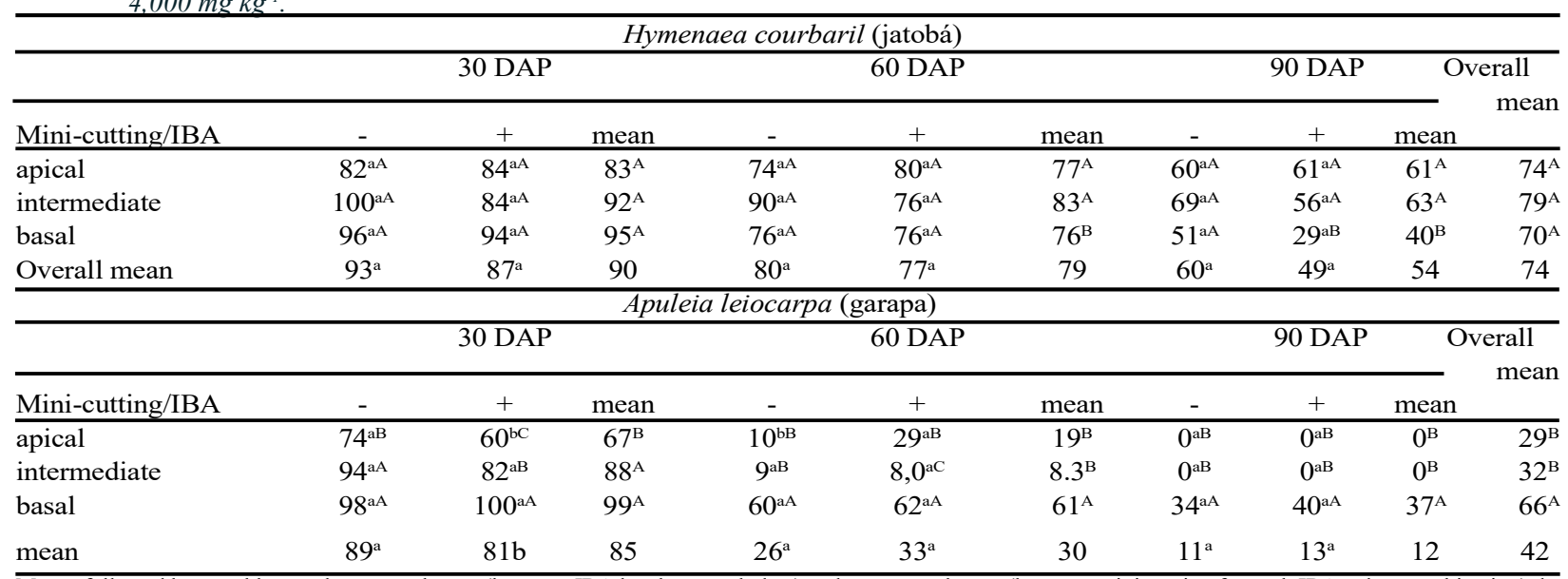

Means followed by equal letters, lowercase letters (between IBA levels on each date) and uppercase letters (between mini-cutting for each IBA x date combination) do not differ from each other by the F-test and the Scott-Knott clustering method at $5 \%$ probability, respectively.

Médias seguidas de letras iguais, minúsculas na linha (entre níveis de AIB em cada data) e maiúsculas na coluna (entre miniestacas para cada combinação entre AIB x data), não diferem entre si pelo teste $\mathrm{F}$ e método de agrupamento de Scott-Knott a 5\% de probabilidade, respectivamente. 
apical mini-cuttings, and $7.6 \%(n=23)$ of intermediate mini-cuttings.

\subsection{Experiment 2}

The basal mini-cuttings were higher than the others at 30,60 and 90 days after planting (Table 2). Intermediate mini-cuttings had significantly higher survival than apical 30 days, regardless of IBA concentration. However, the survival of the intermediate cuttings at 60 and 90 days was equal to the apical minicuttings. Survival behavior of mini-cuttings decreased over time for apical,basal and intermediate mini-cuttings (Figure 1a).

The rooting percentage showed the same behavior as the survival percentage, with only a significant double interaction between cuttings and time at $5 \%$ probability. There was no significant adjustment of the regression model between the different IBA concentrations for each mini-cut $x$ time combination, nor in the overall mean for survival and rooting (\%).

Regardless of IBA concentration (on average), only basal mini-cuttings emitted roots at 60 and 90 days after planting, statistically differing from the apical and intermediate cuttings, in which rooting was null (Table 2).

There was a significant interaction of the minicut type $\mathrm{x}$ IBA and mini-cut type $\mathrm{x}$ time regarding the number and length of roots in garapa mini-cuttings. Only the basal garapa mini-cuts had roots. The average number of roots for this mini-cutting technique was 1.2 at 60 days and 2.9 at 90 days (Table 3). The other types of mini-cuttings did not take root, regardless of IBA doses. The quadratic regression model for basal mini-cuttings was adjusted between IBA concentrations with minimum point inflection on the average of the evaluation dates, with the minimum number of roots (0.6) estimated at the dosage $2142 \mathrm{mg} \mathrm{kg}^{-1}$ IBA (Figure $1 b)$.

The mean root length of the basal mini-cuttings was $1.4 \mathrm{~cm}$ at 60 days and $5.6 \mathrm{~cm}$ at 90 days, regardless of the IBA concentration (Table 3). Considering the mean dates for the basal mini-cut, there was an adjustment in the quadratic regression model between IBA concentrations, with minimum root length $(2.3 \mathrm{~cm})$ estimated at $2700 \mathrm{mg} \mathrm{kg}^{-1}$ IBA (Figure 1c).

The root dry mass followed the same behavior as the number and length of roots, with the mini-cut type $\mathrm{x}$ IBA and mini-cut type $\mathrm{x}$ time interactions being significant. The root dry mass for the basal mini-cuttings was $5.4 \mathrm{mg}$ and $17.9 \mathrm{mg}$ at 60 and 90 days, respectively (Table 3). The root dry mass of the basal mini-cuttings fit in the mean quadratic regression model of the evaluation dates. The lowest root dry mass value $(0.92 \mathrm{mg})$ was estimated at $2833 \mathrm{mg} \mathrm{kg}^{-1}$ IBA (Figure 1d).

Table 2 - Average survival percentage of apical, intermediate and basal Apuleia leiocarpa (garapa) minicuttings at 30,60 and 90 days after planting (DAP) with indolebutyric acid (IBA) application at concentrations of $0,1,000,2,000$ and $4,000 \mathrm{mg} \mathrm{kg}^{-1}$.

Tabela 2 - Porcentagem de sobrevivência média de miniestacas apicais, intermediárias e basais de Apuleia leiocarpa (garapa) aos 30, 60 e 90 dias após o plantio (DAP) com aplicação de ácido indolbutírico (AIB) nas concentrações de 0, 1,000, 2,000 e 4,000mg kg-1.

\begin{tabular}{|c|c|c|c|c|c|}
\hline \multicolumn{6}{|c|}{ IBA concentration $\left(\mathrm{mg} \mathrm{kg}^{-1}\right)$} \\
\hline Mini-cutting & 0 & 1000 & 2000 & 4000 & Mean \\
\hline & & 30 DAP & & & \\
\hline apical & $45.0^{\mathrm{c}}$ & $45.0^{\mathrm{c}}$ & $65.0^{\mathrm{b}}$ & $45.0^{\mathrm{c}}$ & $50.0^{\mathrm{c}}$ \\
\hline intermediate & $65.0^{\mathrm{b}}$ & $77.5^{\mathrm{b}}$ & $87.5^{\mathrm{a}}$ & $80.0^{\mathrm{b}}$ & $77.5^{\mathrm{b}}$ \\
\hline basal & $100.0^{\mathrm{a}}$ & $97.5^{\mathrm{a}}$ & $100.0^{\mathrm{a}}$ & $100.0^{\mathrm{a}}$ & $99.4^{\mathrm{a}}$ \\
\hline & & 60 DAP & & & \\
\hline apical & $2.5^{\mathrm{b}}$ & $0.0^{\mathrm{b}}$ & $2.5^{\mathrm{b}}$ & $2.5^{\mathrm{b}}$ & $1.9^{\mathrm{b}}$ \\
\hline intermediate & $2.5^{\mathrm{b}}$ & $2.5^{\mathrm{b}}$ & $17.5^{\mathrm{b}}$ & $15^{\mathrm{b}}$ & $9.4^{\mathrm{b}}$ \\
\hline basal & $95.0^{\mathrm{a}}$ & $90.0^{\mathrm{a}}$ & $87.5^{\mathrm{a}}$ & $97.5^{\mathrm{a}}$ & $92.5^{\mathrm{a}}$ \\
\hline & & 90 DAP & & & \\
\hline apical & $0.0^{\mathrm{b}}$ & $0.0^{\mathrm{b}}$ & $0.0^{\mathrm{b}}$ & $0.0^{\mathrm{b}}$ & $0.0^{\mathrm{b}}$ \\
\hline intermediate & $0.0^{\mathrm{b}}$ & $0.0^{\mathrm{b}}$ & $5.3^{\mathrm{b}}$ & $0.0^{\mathrm{b}}$ & $1.3^{\mathrm{b}}$ \\
\hline basal & $77.3^{\mathrm{a}}$ & $73.9^{\mathrm{a}}$ & $69.6^{\mathrm{a}}$ & $77.3^{\mathrm{a}}$ & $74.5^{\mathrm{a}}$ \\
\hline Overall mean & 25.8 & 24.6 & 24.9 & 25.8 & 25.3 \\
\hline
\end{tabular}

Averages followed by equal letters in the column do not differ from each other by the Scott-Knott clustering method at 5\% probability.

Médias seguidas por letras iguais na coluna, não diferem entre si pelo método de agrupamento de Scott-Knott a $5 \%$ de probabilidade. 
Table 3 - Rooting, number, length and root mass of Apuleia leiocarpa (garapa) apical, intermediate and basal mini-cuttings evaluated 60 and 90 days after planting (DAP) with application of different IBA concentrations.

Tabela 3 - Enraizamento, número, comprimento e massa de raízes de miniestacas apicais, intermediárias e basais de Apuleia leiocarpa (garapa) avaliadas 60 e 90 dias após o plantio (DAP) com aplicação de diferentes concentrações de AIB.

\begin{tabular}{|c|c|c|c|c|c|c|}
\hline \multicolumn{7}{|c|}{ Rooting (\%) } \\
\hline IBA & Apical & Intermediate & Basal & Apical & Intermediate & Basal \\
\hline & \multicolumn{3}{|c|}{60 DAP } & \multicolumn{3}{|c|}{90 DAP } \\
\hline 0 & $\overline{0^{\mathrm{b}}}$ & $0^{\mathrm{b}}$ & $20^{\mathrm{a}}$ & $0^{\mathrm{b}}$ & $0^{\mathrm{b}}$ & $40^{\mathrm{a}}$ \\
\hline 1000 & $0^{\mathrm{a}}$ & $0^{\mathrm{a}}$ & $5^{\mathrm{a}}$ & $0^{\mathrm{b}}$ & $0^{\mathrm{b}}$ & $25^{\mathrm{a}}$ \\
\hline 2000 & $0^{\mathrm{a}}$ & $0^{\mathrm{a}}$ & $0^{\mathrm{a}}$ & $0^{\mathrm{b}}$ & $0^{\mathrm{b}}$ & $25^{\mathrm{a}}$ \\
\hline 4000 & $0^{\mathrm{a}}$ & $0^{\mathrm{a}}$ & $10^{\mathrm{a}}$ & $0^{\mathrm{b}}$ & $0^{\mathrm{b}}$ & $35^{\mathrm{a}}$ \\
\hline Mean & $0^{\mathrm{b}}$ & $0^{\mathrm{b}}$ & $8.8^{\mathrm{a}}$ & $0^{\mathrm{b}}$ & $0^{\mathrm{b}}$ & $31.3^{\mathrm{a}}$ \\
\hline \multicolumn{7}{|c|}{ Number of roots $(n)$} \\
\hline \multirow[t]{2}{*}{ IBA } & Apical & Intermediate & Basal & Apical & Intermediate & Basal \\
\hline & \multicolumn{3}{|c|}{60 DAP } & \multicolumn{3}{|c|}{90 DAP } \\
\hline 0 & $\overline{0^{\mathrm{b}}}$ & $0^{\mathrm{b}}$ & $3.6^{\mathrm{a}}$ & $0^{\mathrm{b}}$ & $0^{\mathrm{b}}$ & $4.2^{\mathrm{a}}$ \\
\hline 1000 & $0^{\mathrm{b}}$ & $0^{\mathrm{b}}$ & $0.4^{\mathrm{a}}$ & $0^{\mathrm{b}}$ & $0^{\mathrm{b}}$ & $2.0^{\mathrm{a}}$ \\
\hline 2000 & $0^{\mathrm{a}}$ & $0^{\mathrm{a}}$ & $0^{\mathrm{a}}$ & $0^{\mathrm{a}}$ & $0^{\mathrm{a}}$ & $1.3^{\mathrm{a}}$ \\
\hline 4000 & $0^{\mathrm{a}}$ & $0^{\mathrm{a}}$ & $0.8^{\mathrm{a}}$ & $0^{\mathrm{b}}$ & $0^{\mathrm{b}}$ & $4.1^{\mathrm{a}}$ \\
\hline Mean & $0^{\mathrm{b}}$ & $0^{\mathrm{b}}$ & $1.2^{\mathrm{a}}$ & $0^{\mathrm{b}}$ & $0^{\mathrm{b}}$ & $2.9^{\mathrm{a}}$ \\
\hline \multicolumn{7}{|c|}{ Root length $(\mathrm{cm})$} \\
\hline \multirow[t]{2}{*}{$\mathrm{IBA}$} & Apical & Intermediate & Basal & Apical & Intermediate & $\overline{\text { Basal }}$ \\
\hline & \multicolumn{3}{|c|}{$60 \mathrm{DAP}$} & \multicolumn{3}{|c|}{$90 \mathrm{DAP}$} \\
\hline 0 & $\overline{0^{b}}$ & $0^{\mathrm{b}}$ & $3.7^{\mathrm{a}}$ & $0^{\mathrm{b}}$ & $0^{\mathrm{b}}$ & $8.1^{\mathrm{a}}$ \\
\hline 1000 & $0^{\mathrm{a}}$ & $0^{\mathrm{a}}$ & $1.4^{\mathrm{a}}$ & $0^{\mathrm{b}}$ & $0^{\mathrm{b}}$ & $6.0^{\mathrm{a}}$ \\
\hline 2000 & $0^{\mathrm{a}}$ & $0^{\mathrm{a}}$ & $0^{\mathrm{a}}$ & $0^{\mathrm{b}}$ & $0^{\mathrm{b}}$ & $4.5^{\mathrm{a}}$ \\
\hline 4000 & $0^{\mathrm{a}}$ & $0^{\mathrm{a}}$ & $0.6^{\mathrm{a}}$ & $0^{\mathrm{b}}$ & $0^{\mathrm{b}}$ & $3.9^{\mathrm{a}}$ \\
\hline Mean & $0^{\mathrm{b}}$ & $0^{\mathrm{b}}$ & $1.4^{\mathrm{a}}$ & $0^{\mathrm{b}}$ & $0^{\mathrm{b}}$ & $5.6^{\mathrm{a}}$ \\
\hline \multicolumn{7}{|c|}{ Root mass (mg) } \\
\hline \multirow[t]{2}{*}{ AIB } & Apical & Intermediate & Basal & Apical & Intermediate & $\overline{\text { Basal }}$ \\
\hline & \multicolumn{3}{|c|}{60 DAP } & \multicolumn{3}{|c|}{90 DAP } \\
\hline 0 & $\overline{0^{\mathrm{b}}}$ & $0^{\mathrm{b}}$ & $18.6^{\mathrm{a}}$ & $0^{\mathrm{b}}$ & $0^{\mathrm{b}}$ & $31.2^{\mathrm{a}}$ \\
\hline 1000 & $0^{\mathrm{a}}$ & $0^{\mathrm{a}}$ & $2.3^{\mathrm{a}}$ & $0^{\mathrm{b}}$ & $0^{\mathrm{b}}$ & $20.4^{\mathrm{a}}$ \\
\hline 2000 & $0^{\mathrm{a}}$ & $0^{\mathrm{a}}$ & $0^{\mathrm{a}}$ & $0^{\mathrm{a}}$ & $0^{\mathrm{a}}$ & $6.6^{\mathrm{a}}$ \\
\hline 4000 & $0^{\mathrm{a}}$ & $0^{\mathrm{a}}$ & $0.8^{\mathrm{a}}$ & $0^{\mathrm{b}}$ & $0^{\mathrm{b}}$ & $13.3^{\mathrm{a}}$ \\
\hline Mean & $0^{\mathrm{b}}$ & $0^{\mathrm{b}}$ & $5.4^{\mathrm{a}}$ & $0^{\mathrm{b}}$ & $0^{\mathrm{b}}$ & $17.9^{\mathrm{a}}$ \\
\hline
\end{tabular}

Means followed by equal letters on the line do not differ from each other by the Scott-Knott clustering method at $5 \%$ probability.

Médias seguidas de letras iguais na linha, não diferem entre si pelo método de agrupamento de Scott-Knott a $5 \%$ de probabilidade.

\section{DISCUSSION}

Jatobá did not show vegetative propagation viability by mini-cutting technique due to the low rooting. Some species such as Combretum leprosum Mart (Oliveira et al., 2014) and Plathymenia reticulata Benth (Pessanha et al., 2018) have also shown difficulty in vegetative propagation. Several factors can influence the survival of the mini-cutting, such as the occurrence of injuries, hormonal balance, the genetic constitution of the mother plant, the endogenous level of inhibitors, climatic, nutritional and health factors (Xavier et al., 2009).

IBA had no significant influence on rooting success and survival of garapa mini-cuttings, and the concentrations used reduced the number, length and dry mass of roots. According to Botin and Carvalho (2015), auxins are growth regulators which induce root formation in cuttings, but in some cases have little or no effect on species with difficult rooting, and may even have toxicity. Other already studied species have also shown no response to IBA in relation to cutting survival or rooting, among which we can highlight Eucalyptus grandis Hill ex Maiden (Titon et al., 2003), Campomanesia aurea O. Berg (Emer et al., 2016) and Buxus sempervirens L. (Vieira et al., 2018).

The lack of response to auxin in some species may be due to the high degree of lignification of minicuttings, thereby making IBA action difficult (Hartmann et al., 2011). Another hypothesis may be the need for high

Revista Árvore 2020;44:e4405 

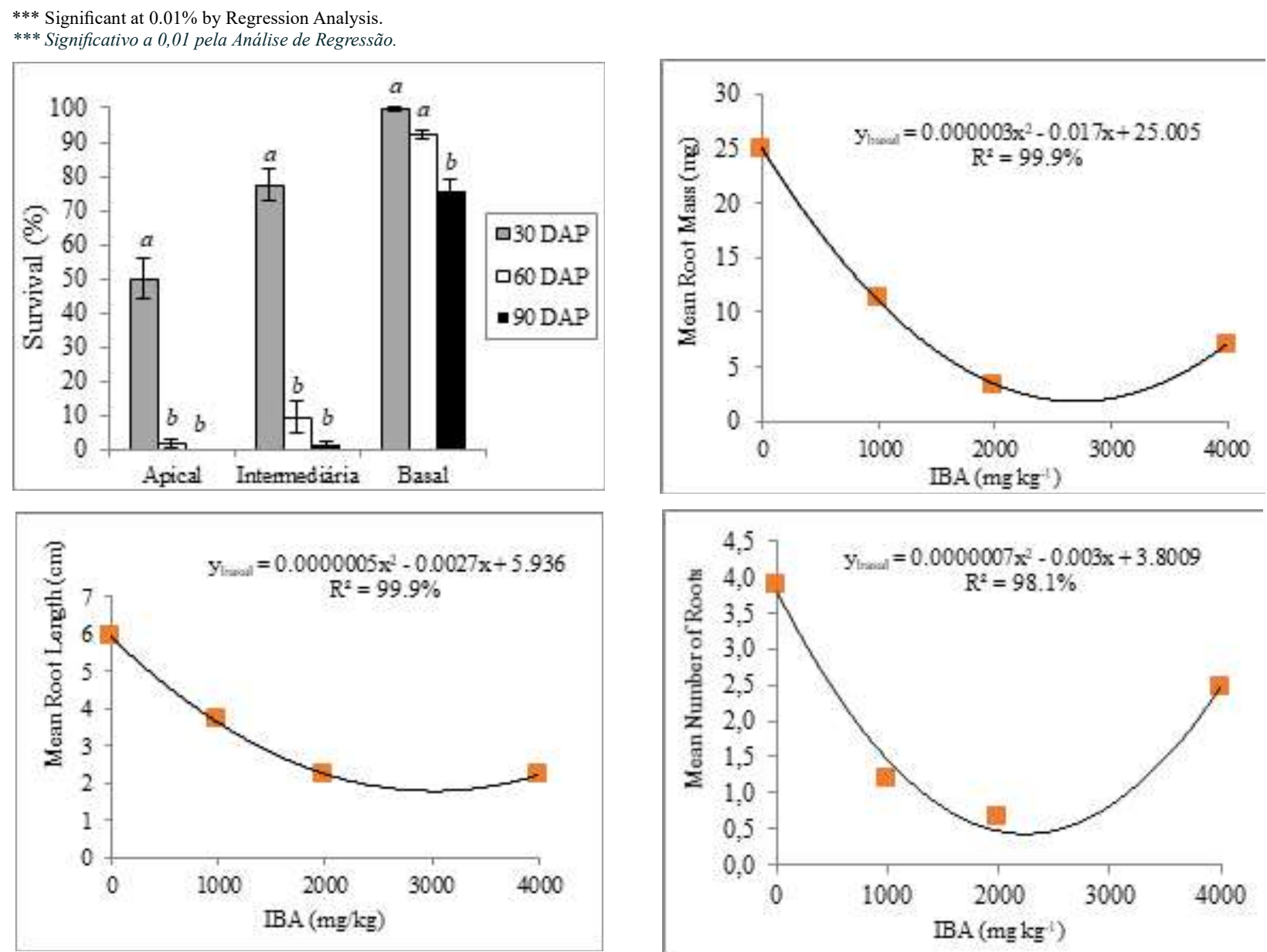

Figure 1 - Survival of Apuleia leiocarpa mini-cuttings up to 90 days after planting (DAP) (a); Average number of roots (b); average length of roots (c); root dry matter mass (d) of Apuleia leiocarpa basal mini-cuttings 90 days after planting as a result of IBA application.

Figura 1 - Sobrevivência de miniestacas de Apuleia leiocarpa até 90 dias após o plantio (DAP) (a); Número médio de raízes (b); comprimento médio de raizes (c); massa de matéria seca de raizes (d) de miniestacas basais de Apuleia leiocarpa após 90 dias

doses of IBA to express its effect, as reported by Dias et al. (2015), using doses of $0,8,000,16,000$ and 32,000 $\mathrm{mg} \mathrm{L}^{-1}$ of IBA in Schizolobium amazonicum Herb. minicuttings, obtaining better rooting results in the highest dose. Oliveira et al. (2015) also only found adventitious root response in Handroanthus heptaphyllus Mattos apical mini-cuttings at a dose of $8,000 \mathrm{mg} \mathrm{L}^{-1}$ after testing lower concentrations $(0,2,000,4,000,6,000 \mathrm{mg}$ $\mathrm{L}^{-1}$ of IBA).

It is important to highlight that cuttings may have sufficient endogenous auxin levels in their tissues to promote root formation (Hartmann et al., 2011). Thus, the exogenous application of growth regulators to vegetative propagules, especially auxins, can sometimes damage cuttings. Mantovani et al. (2017) observed that the application of IBA, as well as the increase in concentrations, caused a reduction in the survival percentage of Peltophorum dubium Spreg. Taub. apical and basal mini-cuttings. For Nachtigal et al. (1994), increasing IBA concentrations up to $400 \mathrm{mg} \mathrm{L}^{-1}$ using slow immersion of the base of herbaceous cuttings of araçá for 16 hours increased leaf fall and cutting death; they correlated this fact with the phytotoxic effect of the IBA.

The basal garapa mini-cutting had the best performance in relation to the intermediate and apical mini-cuttings, while there was no difference between the mini-cutting techniques used for jatobá. According 
to Hartmann et al. (2011), less lignified (herbaceous) cuttings are more sensitive to dehydration and death, which may justify the mortality of apical and intermediate cuttings. For Druege et al. (2004), cutting survival may be limited by their initial reserve, which varies between cutting technique and their lignification degree. In a study conducted with Acca sellowiana, Berg.Franzon et al. (2004) found that cuttings of the apical portion of the branches did not survive the 60-day period in a greenhouse. On the other hand, Mantovani et al. (2017) observed a higher survival (100\%) and rooting percentage of apical mini-cuttings when compared to basal (60\%) mini-cuttings in Peltophorum dubium.

The $40 \%$ rooting found for basal garapa minicuttings at 90 days can be considered median. In species such as Plinia cauliflora (DC.) Kausel apical herbaceous cuttings reached a maximum of $10 \%$ rooting when submitted to IBA concentrations ranging from 2000 to $4000 \mathrm{mg} \mathrm{L}^{-1}$ (Sasso et al., 2010). The best result for Campomanesia adamantium (Cambess.) O. Berg was $57 \%$ rooting without the use of exogenous auxin collected from hardwood cuttings obtained in May (Martins et al., 2015). In addition, the best result for Campomanesia aurea (O. Berg) was $30 \%$ for rooting of semi-wood cuttings without positive response to IBA application (Emer et al., 2016). Freitas et al. (2017a) found 53\% rooting for Enterolobium contortisiliquum (Vell.) Morong produced in mini-greenhouse PET bottles. Pessanha et al. (2018) obtained an average of $16 \%$ rooting in Plathymenia reticulata without an influence of IBA use.

The effects of IBA on higher dry matter yield, length and/or root number have already been reported by Sampaio et al. (2010) in the rooting of preciosa cuttings (Aniba canelilla (Kunth) Mez), by Mantovani et al. (2017) in Peltophorum dubium mini-cuttings, and by Oliveira et al. (2015) for Handroanthus heptaphyllus Mattos mini-cuttings. However, these effects were not verified in the concentrations used in this work.

\section{CONCLUSIONS}

- The use of mini-cuttings proved to be technically viable for the vegetative propagation of Apuleia leiocarpa, with the use of basal cuttings as vegetative propagules being more effective, without the need for IBA.

- IBA was detrimental to the Apuleia leiocarpa rooting at the concentrations used, which was reflected in the lower dry matter yield, number and length of mini-cut roots.

- Hymenaea courbaril did not adapt to the propagation process via mini-cutting in the conditions under which the experiment was carried out, and further studies with vegetative propagation of this species are necessary.

\section{REFERENCES}

Bisognin DA, Lencina KH, Kielse P, Fleig FD, Silveira R, Gimenes ES. Cuttings of post fire epicormic shoots of Ilex paraguariensis and Cabralea canjerana adult plants. Ciência Rural. 2017;47(3):e20151287. doi: http://dx.doi.org/10.1590/0103-8478cr20151287

Botin AA, Carvalho A. Reguladores de crescimento na produção de mudas florestais. Revista de Ciências Agroambientais. 2015;13(1):83-96. Disponível em: http://www.unemat.br/revistas/rcaa/docs/vol13-1/10_ artigo_rcaa_v13n1a2015.pdf

Carvalho PER. Espécies arbóreas brasileiras. Colombo: EMBRAPA/CNPR, Brasília: EMBRAPA-SPI; 2003. v.1. ISBN 978-85-7383-487-1.

Cavalcante UR, Megguer CA, Vieira JS, Dionísio F, Vilarinho MS. Influence of different parts of cuttings and substrates on vegetative propagation of Pereskia aculeata Miller. Bioscience Journal. 2019;35(3):69199. doi: 10.14393/BJ-v35n3a2019-40717

CNC Flora. Apuleia leiocarpa in Lista Vermelha da flora brasileira versão 2012.2 Centro Nacional de Conservação da Flora. Disponível em: < http://cncflora. jbrj.gov.br/portal/pt-br/profile/Apuleia leiocarpa $>$. Acesso em: 13 junho 2019.

Oliveira TPDF, Barroso DG, Lamônica KR, Carvalho VS, De Oliveira MA. Efeito do ácido indol-3-butírico (AIB) no enraizamento de miniestacas de ipê-roxo (Handroanthus heptaphyllus Mattos). Ciência Florestal. 2015;25(4):1043-1051. doi:10.5902/1980509820666

Oliveira DM, Ribeiro MCC, Benedito CP, Paiva

EP, Sá FVS. Estaquia para propagação vegetativa do mofumbo. Revista Verde de Agroecologia e Desenvolvimento Sustentável. 2014;9(1):163-167. 
Disponível em: https://www.gvaa.com.br/revista/index. php/RVADS/article/view/2660

Dias PC, Oliveira LS, Xavier A, Wendling I. Estaquia e miniestaquia de espécies florestais lenhosas do Brasil. Pesquisa Florestal Brasileira. 2012;32(72):453-462. doi: $10.4336 / 2012$.pfb.32.72.453

Dias PC, Ataíde GM, Xavier A, Oliveira LS, Paiva HN. Propagação vegetativa de Schizolobium amazonicum por estaquia. Revista Cerne. 2015;21(3):379-386. doi: $10.1590 / 01047760201521031467$

Druege U, Zerche S, Kadner R. Nitrogen and storageaffected carbohydrate partitioning in high-light-adapted Pelargonium cuttings in relation to survival and adventitious root formation under low light. Annals of Botany. 2004;94(6):831-842. doi: 10.1093/aob/mch210

Emer AA, Schafer G, Avrella ED, Delazeri M, Veit PA, Fior CS. Influence of indolebutyric acid in the rooting of Campomanesia aurea semihardwood cuttings. Ornamental Horticulture. 2016;22(1):94-100. doi: 10.14295/oh.v22i1.855

Endres L, Marroquim PMG, Santos CM, Souza NNF. Enraizamento de estacas de pau-brasil (Caesalpinia echinata Lam.) tratadas com ácido indolbutírico e ácido naftaleno acético. Ciência Rural. 2007;37(3):886-889. doi: 10.1590/S0103-84782007000300046

Ferriani AP, Zuffellato-Ribas KC, Wendling I. Miniestaquia aplicada a espécies florestais. Revista Agro@mbiente On-line. 2010;4(2):102-109. Disponível em: https://revista.ufrr.br/agroambiente/ article/view/363/300

Franzon RC, Antunes LEC, Raseira MCB. Efeito do AIB e de diferentes tipos de estaca na propagação vegetativa da goiabeira-serrana (Acca sellowiana Berg). Revista Brasileira de Agrociência. 2004;10(4):515-518. doi: 10.18539/CAST.V10I4.1036

Freitas TAS, Pimenta DAL, Mendonça AVR. Enraizamento de miniestacas de Enterolobium contortisiliquum em garrafas PET. Revista Agrogeoambiental. 2017a;9(3):61-70. doi:10.18406/2316-1817v9n32017968

Freitas RMO, Coelho MFB, Nogueira NW, Leal
CCP, Oliveira AK. Propagação vegetativa de romã com material vegetal de diferentes origens sob tipos de substratos. Revista Verde de Agroecologia e Desenvolvimento Sustentável. 2017b;12(1):29-33. doi: https://doi.org/10.18378/rvads.v12i1.4070

Gonçalves JLDM, Santarelli EG, Moraes Netto SP, Manara MP, Stape JL. Produção de mudas de espécies nativas: substrato, nutrição, sombreamento e fertilização. In: Gonçalves JLM, Benedetti V, editors. Nutrição e fertilização florestal. Piracicaba: IPEF; 2000. p. 309-350. ISBN 9788590135814.

Guimarães RN, Souza ERB, Naves RV, Melo APC, Rubio Neto A. Vegetative propagation of pequi (souari nut) by cutting. Ciência Rural. 2019;49(2):e20180579. doi:10.1590/0103-8478cr20180579

Hartmann HT, Kester DE, Davies Junior FT, Geneve RL. Plant propagation: principles and practices. 8th. ed. New Jersey: Englewood Clipps; 2011. ISBN 978-0-13501449-3.

Hernández W, Xavier A, Paiva HN, Wendling I. Propagação vegetativa do pau-jacaré (Pitadenia gonoacantha (Mart.) Macbr.) por estaquia. Revista Árvore. 2012;36(5):813-823. http://www.redalyc.org/ articulo.oa?id $=48824773003$

Lacerda CF, Enéas Filho J, Pinheiro CB. Fisiologia Vegetal [Internet]. Fortaleza: Universidade Federal do Ceará; 2007. [cited 2019 october 11]. Available from: http://www.fisiologiavegetal.ufc.br/apostila.htm

Lima HC, Pinto RB. Hymenaea in Lista de Espécies da Flora do Brasil [Internet]. Rio de Janeiro: Jardim Botânico do Rio de Janeiro; 2015. [cited 2019 July 04]. Available: http://floradobrasil.jbrj.gov.br/jabot/ floradobrasil/FB22972

Lima HC. Apuleia in Lista de Espécies da Flora do Brasil [Internet]. Rio de Janeiro: Jardim Botânico do Rio de Janeiro; 2015. [cited 2019 July 04]. Available: http://floradobrasil.jbrj.gov.br/jabot/floradobrasil/ FB22796

Lima CC, Ohashi ST, Silveira AS. Efeito de diferentes concentrações de AIB e procedências geográficas no enraizamento de estacas de paricá. Ciência Florestal. 2018;28(3):1282-1292. doi: 10.5902/1980509833380 
Lorenzi H. Árvores brasileiras: manual de identificação e cultivo de plantas arbóreas nativas do Brasil. Nova Odessa: Instituto Plantarum; 1992. v. 1. ISBN: 8586714-07-0.

Mantovani N, Roveda M, Tres L, Fortes FO, Grando MF. Cultivo de canafístula (Peltophorum dubium) em minijardim clonal e propagação por miniestacas. Ciência Florestal. 2017;27(1):225-236. doi:10.5902/1980509826461

Marchi PM, Antunes LEC, Pereira IS, Höhn D, Valgas RA. Vegetative propagation of raspberry from leafy cuttings. Revista Brasileira de Fruticultura. 2018;40(5):e-378. http://dx.doi.org/10.1590/010029452018378

Martins WA, Mantelli M, Santos SC, Netto APC, Pinto F. Estaquia e concentração de reguladores vegetais no enraizamento de Campomanesia adamantium. Revista de Ciências Agrárias. 2015;38(1):58-64. Disponível em: http://www.scielo.mec.pt/pdf/rca/v38n1/v38n1a09. pdf

Menezes A, Sampaio PTB, Blind AD. Propagação de pau-rosa (Aniba rosaeodora Ducke) por estacas e miniestacas. Nucleus - Revista Científica da Fundação Educacional de Ituverava. 2018;15(1):515-522. doi: $10.3738 / 1982.2278 .1829$

Nachtigal JC, Hoffmann A, Kluge RA, Fachinello JC, Mazzini AR. Enraizamento de estacas semilenhosas de araçazeiro (Psidium cattleyanum Sabine) com o uso do ácido indolbutírico. Revista Brasileira de Fruticultura. 1994;16(1):229-235.

Neubert VF, Xavier A, Paiva HN, Dias PC, Gallo $\mathrm{R}$. Production of mini-cuttings and the influence of leaf reduction on rooting of vinhático (Plathymenia foliolosa Benth.). Revista Árvore. 2017;41(4):e410402. doi:10.1590/1806-90882017000400002

Peralta MDLÁM, Nava JRG, Santos GGDL, García ARR, Salado NT. Reguladores del crecimiento y sustratos en la propagación vegetativa de nanche (Malpighia mexicana A. Juss. y Byrsonima crassifolia (L) H.B.K). Revista Brasileira de Fruticultura. 2017;39(3):e-700. doi:10.1590/0100-29452017700

Pessanha SEGL, Barroso DG, Barros TC, Oliveira TPF,
Carvalho GCMW, Cunha M. Limitações na produção de vinhático (Plathymenia reticulata Benth) por miniestaquia. Ciência Florestal. 2018;28(4):1688-1703. doi: $10.5902 / 1980509835317$

R Development Core Team. R: A language and environment for statistical computing. Vienna, Austria: R Foundation for Statistical Computing; 2018. Available from: <URL https://www.R-project.org/>.

Ramos DP, Castro AF, Camargo MN. Levantamento detalhado de solos da área da Universidade Federal Rural do Rio de Janeiro. Pesq. Agrop. Brasileira. 1973;8:1-27.

Sampaio PTB, Siqueira JAS, Costa S, Bruno FMS. Propagação vegetativa por miniestacas de preciosa (Aniba canellila (H.B.K) Mez). Acta Amazonica. 2010;40(4):687-692. doi:10.1590/S004459672010000400007

Sasso SAZ, Citadin I, Danner MA. Propagação de jabuticabeira por estaquia. Revista Brasileira de Fruticultura. 2010;32(2):577-583. doi: 10.1590/S010029452010005000054

Titon M, Xavier A, Otoni WC, Reis GG. Efeito do AIB no enraizamento de miniestacas e microestacas de clones de Eucalyptus grandis W. Hill ex Maiden. Revista Árvore. 2003;27(1):1-7. doi: 10.1590/S010067622003000100001

Valmorbida J, Boaro CSF, Lessa AO, Salerno AR. Enraizamento de estacas de Trichilia catigua A. Juss (catigua) em diferentes estações do ano. Revista Árvore. 2008;32(3):435-442. doi: http://dx.doi. org/10.1590/S0100-67622008000300006

Vieira LM, Kruchelski S, Gomes EN, Zuffellato-Ribas $\mathrm{KC}$. Indolebutyric acid on boxwood propagation by stem cuttings. Ornamental Horticulture.

2018;24(4):347-352.doi: 10.14295/oh.v24i4.1185

Xavier A, Wendeling I, Silva RL. Silvicultura clonal: princípios e técnicas. Viçosa: Universidade Federal de Viçosa; 2009. ISBN 9788572693493.

Yamamoto LY, Borges RS, Sorace M, Rachid BF, Ruas JMF, Sato O, et al. Enraizamento de estacas de

Revista Árvore 2020;44:e4405 
Psidium guajava L.'Século XXI' tratadas com ácido indolbutírico veiculado em talco e álcool. Ciência
Rural. 2010;40(5):1037-1042. doi: http://dx.doi. org/10.1590/S0103-84782010000500006 